\title{
Article
}

\section{Understanding Early Elementary Children's Conceptual Knowledge of Plant Structure and Function through Drawings}

\author{
Janice L. Anderson, ${ }^{*}$ Jane P. Ellis, $^{\dagger}$ and Alan M. Jones ${ }^{\ddagger}$ \\ *School of Education and $\ddagger$ Department of Biology, University of North Carolina at Chapel Hill, \\ Chapel Hill, NC 27599; ${ }^{\dagger}$ College of Charleston, Charleston, SC 29455 \\ Submitted December 2, 2013; Revised March 24, 2014; Accepted March 28, 2014 \\ Monitoring Editor: Emily A. Holt
}

\begin{abstract}
This study examined children's drawings to explain children's conceptual understanding of plant structure and function. The study explored whether the children's drawings accurately reflect their conceptual understanding about plants in a manner that can be interpreted by others. Drawing, survey, interview, and observational data were collected from 182 students in grades K and 1 in rural southeastern United States. Results demonstrated the children held a wide range of conceptions concerning plant structure and function. These young children held very simple ideas about plants with respect to both their structure and function. Consistent with the drawings, the interviews presented similar findings.
\end{abstract}

\section{INTRODUCTION}

During the elementary grades, children are exposed to and build understandings of biological concepts through their interactions with the world around them (National Research Council [NRC], 1996, 2012; Tunnicliffe, 2001; French, 2004). These explanations and conceptual understandings develop from children's direct, concrete experiences with living organisms, life cycles, ecosystems, and habitats (NRC,1996, 2012; Tunnicliffe, 2001), with much of this exploration involving the use of their senses, such as touch and smell

DOI: $10.1187 /$ cbe.13-12-0230

Address correspondence to: Janice L. Anderson (anderj1@ email.unc.edu).

Conflict of interest statement: This study was funded in part by a National Science Foundation grant (to A.M.J.) and an American Society of Plant Biology Educational Foundation grant to the authors for the purpose of creating and evaluating a coloring and activity book for pre- and young readers created by two of the authors of this article (J.P.E. and A.M.J.). The authors disclose a potential conflict of interest for endorsement of the book My Life as a Plant, which was used as a research tool in this study.

(C) 2014 J. L. Anderson et al. CBE-Life Sciences Education (C) 2014 The American Society for Cell Biology. This article is distributed by The American Society for Cell Biology under license from the author(s). It is available to the public under an AttributionNoncommercial-Share Alike 3.0 Unported Creative Commons License (http:/ / creativecommons.org/licenses/by-nc-sa/3.0).

"ASCB ${ }^{\mathbb{R}) " ~ a n d ~ " T h e ~ A m e r i c a n ~ S o c i e t y ~ f o r ~ C e l l ~ B i o l o g y ~}{ }^{(\mathbb{R})}$ are registered trademarks of The American Society for Cell Biology.
(Tunnicliffe, 2001). Despite these experiences, research has shown that both children and adults often develop an understanding about the natural world that is much different from what is presented by the scientific community (e.g., Osborne and Freyberg, 1985; Gauld, 1989; Howe et al., 2011; Wee, 2012). This has been shown to be the case when examining how plants are introduced into the science curriculum.

An analysis of elementary school science has demonstrated that plants are underrepresented in the curriculum, contributing to a "plant blindness" in our culture (Wandersee and Schussler, 2001; Lally et al., 2007). Young children have an innate interest in plants, but as they grow older, this interest wanes (Schneekloth, 1989). This has been attributed to how plants are described-as immobile, faceless objects with a nonthreatening presence (Wandersee and Schussler, 2001). Because of this perceived lack of interest by children (and adults), plants are often overlooked in the curriculum by teachers (Sanders, 2007) despite their importance within ecosystems. As a result, research regarding plants and young children has been limited (Tunnicliffe, 2001; Boulter et al., 2003; Gatt et al., 2007), particularly at the early childhood (K-3) level. In the limited studies available, Barman et al. (2006) found that misconceptions about plants and plant growth are introduced and reinforced at early ages. For example, in a study by Bell (1981), children did not consider trees to be plants. This study (Bell, 1981) also found that many children did not consider an organism to be a plant unless it had a flowering structure, whereas other children thought that other organisms or even nonliving things were plants 
because they perceived them to have a "flower" structure. In a later study by McNair and Stein (2001), it was also demonstrated that when asked to draw a plant, both children and adults typically drew a flowering plant.

Children's conceptual understandings of science topics, such as plant structure and function, and the development of science process skills begin during the first year of life (Carey, 2004; Piaget and Inhelder, 2013). Young children have the capability of and are competent in asking questions and making predictions-cognitive skills that set the stage for formal science learning in the early elementary grades (e.g., Kuhn and Pearsall, 2000; Opfer and Siegler, 2004). Previous research has demonstrated that these early learning experiences set the foundation for the development of children's cognitive capabilities (e.g., Brecht and Schmitz, 2008). Still others have advocated for a more balanced approach between natural explanation and academic learning (e.g., Bredekamp, 2006; Bodrova, 2008).

\section{CHILDREN'S CONCEPTIONS OF PLANTS}

Early elementary years (e.g., kindergarten and first grade) capture children in their most formative years of cognitive development. Long before entering formal education, children begin asking questions and engaging with the natural and physical world. This engagement results in children constructing explanations for things they observe from their everyday experiences. These explanations are often different from scientific explanations (Osborne and Freyberg, 1985; Gauld, 1989; Suping, 2003; Howe et al., 2011; Wee, 2012) and are frequently labeled as "misconceptions."

There has been a lack of agreement within science education about whether children's misconceptions should be considered obstacles or resources for teachers to build upon (Larkin, 2012). When misconceptions are characterized as mistakes, it minimizes the role they play in children's learning. Instead, misconceptions can become resources that can be utilized as starting points for science instruction (Smith et al., 1993). For example, young children often believe that plants need milk to grow and develop much like they need milk (e.g., Roth, 1984; Smith and Anderson, 1984). This could be used as a starting point for what plants really need to grow and develop. Additionally, Vosniadou (2002) argues that misconceptions are, in fact, naive conceptions that result from a complex process by which children organize their perceptual experiences and information they gather from the natural and physical world. Because many of these conceptions are seen as fragmented, they may not need to be replaced, but instead reorganized through instruction (Vosniadou, 2002).

Plants are the connection between the sun and energy flow on Earth. According to the National Science Frameworks (NRC, 2012) and the Next Generation Science Standards (Achieve, 2013), students in elementary grades (grades K-5) should understand: 1 ) the basic structure, growth, and development of plants;2) plants have basic needs that include air, water, nutrients, and light, all of which they can receive in their respective environments; 3) environmental changes can impact the survival of plants; 4) plants must reproduce in order to survive; 5) plants respond to external inputs (e.g., turning leaves toward the sun); and 6) the differences in characteristics between individuals of the same species pro- vide advantages in survival (Table 1). When examining plant growth needs, students' ideas and conceptions become more complex, resulting in the emergence of various misconceptions. Where student misconceptions arise is in their conflation of ideas around what plant needs are provided by people (e.g., house plants, gardens) as opposed to what plants receive from their environment (Barman et al., 2006; Anderson et al., 2013). Additionally, younger students will often anthropomorphize explanations around plant structure and function with respect to their own life experiences (Osborne and Freyberg 1985; McNair and Stein, 2001; Barman et al., 2006; Anderson et al., 2013). For example, students will often ascribe that plants need food in much the same way that people need food. When they learn about plants making their own food, they will often think about that food in terms of what a plant ingests, much like how they ingest food on a daily basis (Roth, 1984; Smith and Anderson, 1984; Anderson et al., 2013). These misconceptions often are a direct result of their own experiences with plants in their everyday lives (e.g., planting gardens, taking care of house/class plants).

Because plant structure and function play such an important role in the science education standards and frameworks (see Table 1), creating a progression of learning across the $\mathrm{K}$ 12 grade bands (NRC, 1996, 2012), it is important to understand children's thinking about these topics. Children have experiences on a daily basis with plants from an early age. Unfortunately, this has resulted in misconceptions being introduced and/or reinforced at early ages. The purpose of this study is to examine young children's understanding of plant structure and function in early elementary classrooms. In this study, we are defining early elementary as kindergarten and first grade. Specifically, we examine, through the use of drawings, survey, and interviews: What do early elementary children's drawings indicate about their understanding of plant structure and function?

\section{CONCEPTUAL FRAMEWORK: USING CHILDREN'S DRAWINGS AS A METHOD OF CONCEPTUAL ANALYSIS}

Children's drawings have been used as a mechanism to their sense making in ways that differ from written or spoken text (Haney et al., 2004). Drawings enable children to express what they cannot always verbalize (Grungeon, 1993), with pictures often giving insight into the way children think (Weber and Mitchell, 1995; Einarsdottir et al., 2009). Drawings can also provide insight into a child's representational development (Cherney et al., 2006). Additionally, research has shown (e.g., Tallandini and Valentini, 1991; Cherney et al., 2006) that children's representations differ significantly with age, with young children often drawing simple scribbles and older children drawing objects as they are known, creating visual realism that includes perspective. These drawings become an object that signifies the real thing in an iconic, symbolic representation (Saunders, 1994). As children develop, their drawings become more complex and differentiated in much the same manner as an individual moving toward narrative texts. This represents a movement along a spectrum toward more symbolic imagery (Saunders, 1994; Gabel, 1999).

While previous research focused on the graphic perspective and psychological aspects of children's drawings (e.g., 
Table 1. Next Generation Science Standards and American Society of Plant Biology Principles of Plants

Next Generation Science Standards (Achieve, 2013)

Grade K-2

ASPB 12 Principles of Plants

Earth science 2. Biogeography

Earth science 3.A. Natural resources

Life science 1.A. Structure and function

Life science 1.B. Growth and development of organisms

Life science 1.C. Organization for matter and energy flow in organisms

Life science 2.A. Interdependent relationships in ecosystems

Life science 2.B. Cycles of matter and energy transfer in ecosystems

Life science 2.C. Ecosystem dynamics, functioning, and resilience

Life science 3.A. and 3.B. Inheritance of traits and variation of traits

Life science 4.C Adaptation

Life science 4.D. Biodiversity and humans
Plants and animals can change their local environment.

Living things need water, air, and resources from the land, and they live in places that have the things that they need.

All organisms have external parts that they use to perform daily functions.

Parents and offspring often engage in behaviors that help offspring survive.

Plants need water and light.

Plants depend on water and light to grow, and also depend on animals for pollination or to move their seeds around.

$\mathrm{n} / \mathrm{a}$

$\mathrm{n} / \mathrm{a}$

Young organisms are very much, but not exactly like their parents and also resemble other organisms of the same kind.

$\mathrm{n} / \mathrm{a}$

A range of different organisms lives in different places
Principle 12: Plants live and adapt to a wide variety of environments.

Principle 8: Plants are a primary source of fiber, medicines, and countless other important products in everyday use.

Principle 1: Biological processes of plants

Principle 2: Plant nutrients, growth and development

Principle 11: Control of plant growth

Principle 4: Reproduction of flowering plants Principle 5: Energy, reproduction, and growth Principle 7: Plant diversity

Principle 2: Plant nutrients, growth, and development

Principle 10: Water needs

Principle 11: Control of plant growth

Principle 2: Plant nutrients, growth, and development

Principle 10: Water needs

Principle 3: Plant evolution

Principle 12: Plants live and adapt to a wide variety of environments.

Principle 7: Plant diversity

Principle 5: Energy, reproduction, and growth

Principle 7: Plant diversity

Principle 4: Reproduction

Principle 5: Energy, reproduction, and growth

Principle 7: Plant diversity

Principle 12: Plants live and adapt to a wide variety of environments.

Principle 12: Plants live and adapt to a wide variety of environments.
Goodenough, 1926; Kellogg, 1969; Golomb, 1992; Ring, 2006), recent research has begun to consider children's drawings as ways to express meaning and understanding about their world (Stanczak, 2007). According to Cox (2005), by concentrating on drawing as meaning making takes the focus of the discourse on representation away from the drawings and toward children's intentions. In this sense, a "drawing thus becomes a constructive process of thinking in action, rather than a developing ability to make visual reference to objects in the world" (Cox, 2005, p. 123). We argue that drawings by children involving conceptual knowledge serve as a way to document student thinking, understanding, and change. By focusing on the drawing process, an awareness is built around the narrative that is behind the drawings the children create (Kress, 1997; Einarsdottir et al., 2009), including conceptual understanding. This narrative is connected to how children make meaning in their drawings, allowing for a connection between the social construction of their meaning and what the children strive to convey through their drawings (Light, 1985; Einarsdottir et al., 2009). It is important to consider these narratives in order to understand children's intentions in their drawings. These drawings promote reflection by both stu- dents and teachers about the content being presented and learned (Haney et al., 2004).

Because of this progress, drawings play a significant role in the visualization of scientific ideas and concepts. Drawings help children construct meaning for themselves and allow them to share their ideas with others in varying contexts (Brooks, 2009). Drawings also serve to help young children shift from everyday concepts to more scientific concepts. By creating visual representations of their ideas, children are more able to work at a metacognitive level, revisiting, revising, and talking through complex scientific concepts. Drawing in this sense becomes both a tool of communication and problem solving around abstract ideas (Athney, 1990; Cox, 2005). By creating drawings or visualizations, students begin to move to higher-order thinking while working at a conceptual level. In this way, drawings assess science conceptual knowledge, observational skills, and the ability to reason. Drawings reveal how children perceive an object, such as a plant, and how children make sense of and represent the details of that object (Haney et al., 2004). The open-ended nature of drawings emphasizes ideas and concepts that are interesting to the student and give insight to 
their understanding (McNair and Stein, 2001; Barman et al., 2002).

This is particularly useful in the early grades, when students are just learning how to write. According to Tunnicliffe (2001), what children decide to draw is critical in examining their conceptual understanding about plants. Previous studies (e.g., Bell, 1981; Osborne and Freyberg, 1985; McNair and Stein, 2001; Barman et al., 2002) have demonstrated that students' conceptual understanding of what constitutes a plant is much narrower than what is defined by plant biologists. In this instance, drawings of a plant not only may reflect what students know and understand about the structure of a plant but may give insight into what ideas they have regarding plant function; for example, what the requirements are for plant growth, how plants are able to reproduce, and other common functions (McNair and Stein, 2001).

\section{METHODS}

\section{Study Context: School, Teachers, and Students}

This study was part of a larger design study examining the impact of the pedagogical potential of a plant coloring book created by the American Society for Plant Biologists, entitled My Life as a Plant. In this study, we examined students' conceptual knowledge of plant structure and function. The study occurred in a rural elementary school in the southeastern United States in the early Fall of the school year. Kennedy Elementary School ${ }^{1}$ is a diverse elementary school in Southeastern Public School system. At the time of this study, Kennedy had 594 students in grades $\mathrm{K}-5$. The student body makeup is $42 \%$ Caucasian, $12 \%$ African American, $42 \%$ Latino/a, $1 \%$ Asian, $1 \%$ Native American, and $2 \%$ multiracial. Additionally, $32 \%$ of the students had limited English proficiency and $54 \%$ of the students participated in the free or reduced lunch program. Students in grades K-1 participated in the study and were reflective of the school's demographics $(n=182)$. Teachers of these students were categorized as highly qualified, K-5 elementary educators, with $46 \%$ of the teachers having a master's degree and $15 \%$ being nationally board certified. The school utilizes the Full Option System (FOSS) Science Curriculum from the Lawrence Hall of Science at University of California-Berkeley.

\section{Data Sources}

This study uses both quantitative and qualitative data to provide a holistic view of students' conceptual knowledge of plant structure and function. Data were collected from three primary sources: 1) the Draw-A-Plant instrument; 2) a plant survey; and 3) semistructured interviews. The data collected: 1) documented the students' conceptions about plant structure and function; 2) captured their reasoning through discussion of their drawings; and 3) supported and refuted emerging hypotheses about students' understandings (Barab et al., 2002). In analyzing the data, we utilized a naturalistic inquiry with grounded interpretations (Lincoln and Guba, 1985; Charmaz, 2006). This is consistent with a constructivist perspective, whereby a priority is placed "on the phenomenon of study" of the students and classrooms, with

\footnotetext{
${ }^{1}$ Kennedy Elementary is a pseudonym used for the school.
}

"data and analysis created from shared experiences and relationships with participants and other sources" (Charmaz, 2006, p. 330). Data analysis adhered to the domains of interpretive research that were iterative and inductive, including emergent analytical coding (Haney et al., 2004).

Draw-A-Plant Instrument. As previously discussed, drawings document children's understanding and change around a particular concept and provide an assessment when children are beginning to learn how to write (McNair and Stein, 2001; Haney et al., 2004). Based on this idea, the Draw-A-Scientist (DAST-C) instrument (Chambers, 1983; Finson, 2003) was adapted to plants (see Supplemental Material). Students were asked to think about and draw a picture that showed the parts of a plant and all of the things that plants require for growth. This instrument was designed to gain insight into children's conceptual knowledge about plant structure and function and was previously validated in a pilot study (Anderson et al., 2013). A Cronbach's $\alpha$ was calculated at 0.71 , which, while low, is within an acceptable range of validity. In coding the drawings, we developed and used a checklist that came from emergent analytical coding. This checklist provided a set of features that emerged in analyzing the drawings of the children. Two members of the research team independently reviewed 15 drawings and recorded the various features of the drawings (e.g., flowers, roots, stems, rain, sun). The two checklists were compared and condensed into a list of specific plant features that was then used as a draft-coding sheet. This condensed list was then used to code an additional fifteen drawings. Raters worked independently to code features from the list that were either present or absent. Additionally, the raters looked for features that were present in the drawings but were absent from the code sheet. Coding results were then compared and formal descriptions were developed for structures that had a high level of agreement. Discrepancies were discussed, and the reasons that they occurred were identified. Once common features were identified, a third set of 15 drawings was coded, and an interrater reliability of $r=0.95$ was established. Cohen's kappa $(\kappa)$ was calculated to show that $\kappa=0.84$, which indicates that the frequency with which raters agree is much stronger than by chance alone. This kappa value indicates a strong agreement, which correlates with the interrater reliability. Once final coding schemes were determined, the remaining drawings were coded and the results analyzed.

Plant Survey. In addition to the Draw-A-Plant instrument, a two-part survey was constructed to probe more deeply into students' conceptual knowledge. Surveys were reviewed by both an early childhood and a science educator to ensure that: 1) the format was appropriate; and 2) the surveys were not confusing or misleading to the students. The first part of the survey was designed to determine students' conceptual understanding of what constitutes a plant. This portion of the survey consisted of 13 pictures of plants, nonplants, and objects made from plants. Students were asked to circle all pictures that related to or were specifically plants. The second portion of the survey was designed to determine students' understanding of what plants need in order to survive in their environment. This section of the survey had 12 pictures. Students were asked to circle all pictures that contained materials/objects that plants would need to survive in their environments. Like the Draw-A-Plant instrument, the 
surveys (see Supplemental Material) were previously tested and validated in a study with a similar population (Anderson et al., 2013). A Cronbach's $\alpha$ of 0.78 was calculated and within the acceptable range of validity. Each picture within the survey was scored as 1 , signifying a correct response, or 0 , indicating an incorrect response. On completion, the survey data were analyzed using SPSS and correlated to the corresponding data for the drawings. This allowed us to look across the data to understand student thinking about plant structure and function. Descriptive statistics and frequencies were calculated across the surveys.

Semistructured Interviews. A purposefully selected subset of children who reflected the demographics of the population ( $n=10$ each grade, 20 total) were chosen and interviewed from each grade level. The interview (see Supplemental Material) was constructed to specifically elicit student responses that would provide the researchers with a better understanding of students' performance on the Draw-A-Plant instrument and the surveys demonstrating students' conceptions of plant structure and function. All interviews were digitally audio-recorded and transcribed by the researchers. The interviews were used to verify the coding of the drawings done by the researchers and the surveys that were taken. During the interview, children were asked questions that related specifically to these instruments and their own drawings in order to understand children's reasoning behind their choices and their drawings. For example, cards were created that were identical to the plants and nonplant structures that were found in survey. Students were asked to sort these cards into plant and nonplant structures. After sorting the cards, students were asked to explain their choices. These were then correlated to the responses on the surveys and to the drawings created by the students.

\section{RESULTS AND DISCUSSION}

\section{The Drawings}

The drawing portion of the assessment provided interesting insight into students' conceptual knowledge of plant structure and function. While much of the previous research (e.g., Ross et al., 2006) on students' conceptual understandings of plants has focused on cognitively complex molecular phenomena (e.g., plants respire, accumulation of mass through carbon fixation from air), this study focused on ideas that students gained and demonstrated through their drawings. Drawings varied across the grade levels, with students in first grade beginning to provide more detailed drawings and, in some cases, including secondary objects or materials (e.g., air) that can influence plant growth (see Tables 2 and 3). Additionally, the first grade students began to include other types of organisms in their drawings that they believed helped the plants grow and survive (e.g., bees, worms, birds, seeds). The results from the drawing data are described below. In $72 \%$ of the students' drawings across both grade levels (kindergarten and first grade), sunlight was included in the drawings (Table 4). What emerged in the drawing data were that students were consistent in how they placed sunlight in their drawings.

When the data from the drawings were compared with the surveys, interesting dichotomies occurred across both grade levels. The kindergarten students included the sun in their drawings at a much higher level compared with their survey responses- $-70 \%$ on the drawing assessment compared with $38 \%$ on the survey. Within the first grade, the opposite was seen. The sun was only included in $73 \%$ of the drawings, but $92 \%$ of the students responded on the survey that the sun was necessary for plant growth. The survey data indicated they understood the necessity of sunlight, while their drawings often omitted this important attribute. When asked about this in the interview, several of the students responded that they "just forgot to draw the sun." The current state science curriculum standards presents topics that involve plant structure and/or function in kindergarten and first grade (Table 5). One possible explanation for this increase in the inclusion of the sun in drawings at the first grade level might be attributed to a specific state first grade science standard and curriculum unit on needs of living organisms.

In another finding, air was not commonly drawn, which was not surprising due to its abstract nature. One percent of the drawings from the kindergarten students showed air as an important component, while $10 \%$ of the first graders included air in their drawings (Tables 2 and 3). While these kindergarten and first grade students did not always include air in their drawings, this did not necessarily mean they did not understand the role of air with plants. This was demonstrated in the following example from the interview with Jacinta ${ }^{2}$ :

Interviewer: So I see what you have on your drawing ... What can you tell me about what a plant needs in order to be able to survive/live?

Jacinta: Well ... I had a hard time trying to draw it ... I think air would help the plant to grow .... I can't see air so I didn't really know what it looks like or how I can draw it ... I just decided to not to ... but I know it is important.

Interviewer: So why do you think it's important [air that is]?

Jacinta: Hmmmm, well we need air ... to breathe ... we need it so we can live, so I think that plants must need air too.

In the interviews, Jacinta was one of only two first graders who pointed out the air deficiency in her drawing. One first grade student also included oxygen in his drawing. This was designated by the word "oxygen" with swirls to indicate movement (Table 3). This was an interesting result, given that these concepts are not addressed in either the kindergarten or first grade standards. What this indicated was that, in this particular classroom setting, this student (and potentially others) were exposed to additional science concepts not found in the kindergarten or first grade standards or curriculum. This could potentially reflect back upon the classroom teacher's comfort with and understanding of the science content (e.g., Schwartz et al., 2004) and / or to the prior out-of-school experiences the students bring to the classroom. In further analysis, soil was only drawn and labeled (either as soil or dirt) in 36\% of the drawings across the grade levels; however, students often would draw the ground and not label the ground's consistency. Kindergartners drew soil/dirt in $29 \%$ of their

\footnotetext{
${ }^{2}$ Pseudonyms were used for all of the student names in this study.
} 
Table 2. Example kindergarten student drawings and analysis

\begin{tabular}{|c|c|c|c|}
\hline $\begin{array}{l}\text { Coded drawing } \\
\text { feature }\end{array}$ & $\begin{array}{l}\text { What this indicates about } \\
\text { children's knowledge }\end{array}$ & Example drawing & $\begin{array}{l}\text { Example comment from interview: "So what } \\
\text { can you tell me about your drawing?" }\end{array}$ \\
\hline $\begin{array}{l}\text { Rain, water, } \\
\text { grass, flowers }\end{array}$ & $\begin{array}{l}\text { Recognized the need for water } \\
\text { Recognized flowers as plants }\end{array}$ & 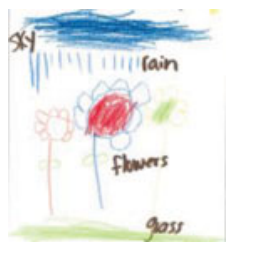 & $\begin{array}{l}\text { Student: Well, I made it rain because plants } \\
\text { need to have water and since they are outside } \\
\text { that is how they get it. }\end{array}$ \\
\hline $\begin{array}{l}\text { Seeds, leaves, } \\
\text { stem, flower, } \\
\text { dirt }\end{array}$ & $\begin{array}{l}\text { Recognized seeds develop from } \\
\text { flowers } \\
\text { Plants have stems and leaves } \\
\text { Flower is a type of plant } \\
\text { Plants need dirt to grow }\end{array}$ & & $\begin{array}{l}\text { Student: So plants need dirt to grow .... and } \\
\text { they have flowers so I drew that. } \\
\text { Interviewer: What else can you tell me about } \\
\text { your drawing? } \\
\text { Student: Plants have stems and leaves and } \\
\text { make seeds like here [points]. }\end{array}$ \\
\hline $\begin{array}{l}\text { Sunlight, water, } \\
\text { rain, flowers, } \\
\text { grass }\end{array}$ & $\begin{array}{l}\text { Recognized the need for sunlight } \\
\text { to grow } \\
\text { Recognized the need for water } \\
\text { Flower is a type of plant }\end{array}$ & 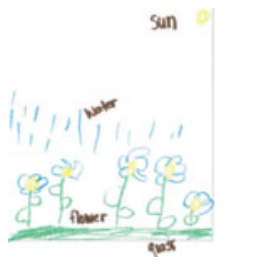 & $\begin{array}{l}\text { Student: So see, I made it sunny out for plants } \\
\text { to grow ... And they need water too, so I } \\
\text { made it rain. } \\
\text { Interviewer: What else can you tell me? } \\
\text { Student: Well, lots of plants have flowers and } \\
\text { they grow in the ground so I drew grass. }\end{array}$ \\
\hline $\begin{array}{l}\text { Rain, water, } \\
\text { flower, grass, } \\
\text { roots }\end{array}$ & $\begin{array}{l}\text { Recognized the need for water } \\
\text { Recognized that plants have roots } \\
\text { that hold them in the ground } \\
\text { Flower is a type of plant }\end{array}$ & 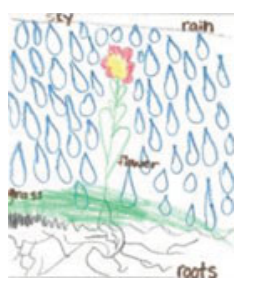 & $\begin{array}{l}\text { Student: So rain comes from the sky and gives } \\
\text { water so they [plants] can grow. } \\
\text { Interviewer: So I see you have some things } \\
\text { drawn at the bottom — can you tell me about } \\
\text { that? } \\
\text { Student: Those are roots to hold up the plant } \\
\text { and get food from the ground. }\end{array}$ \\
\hline
\end{tabular}

drawings. This number increased in first grade to $41 \%$ of the drawings (Table 4). As found in much of the previous research (e.g., Bell, 1981; McNair and Stein, 2001), flowering plants (see Tables 2 and 3.) were drawn more frequently across the grade levels than other plants. When analyzing the details of the drawings, stems were the most commonly drawn plant structure. While these were not always labeled, they were clearly present. What was interesting was that students often did not draw the leaves found on plants, leaving the stems bare, across both the kindergarten and first grade level. Only $6 \%$ of the kindergarten and $22 \%$ of the first grade drawings had leaves drawn on their stems. Another noteworthy finding that emerged in the drawings was the presence or absence of root structures in the drawings. Roots were not found in the kindergarten and in only $14 \%$ of the first grade drawings. When asked about this during the interviews, a number of different responses emerged, including, "I can't see roots so I didn't draw them" to "I forgot to draw things underground." Students understood that the roots helped with water but were unclear about how roots accessed water. From those discussions, it was clear that students knew roots existed, but they had not included them in their drawings. In the section that follows, data from the surveys will be presented and related to the drawings.

\section{The Surveys}

Is It a Plant? In analyzing the survey, one finding appeared across all of the grade levels. When students were presented with pictures of things commonly known to be plants (e.g., trees, flowers), they correctly identified them as plants (Table 6). However, when presented with pictures of plants that were less commonly known (e.g., Venus flytrap) or of everyday materials derived from plants (e.g., paper, peanut butter), students would often mischaracterize these pictures as nonplants.

One of the most common misconceptions students demonstrated was the notion that mushrooms are plants and not fungi. In the interviews, students talked about where they found mushrooms and how they collected them to eat, which, in their conceptualization of food, made them plants. This is seen in the example from the interview with Mariella:

Interviewer: Can you sort these pictures into living things that you think are plants and those that are not 
Table 3. Grade 1 example drawings and analysis

\begin{tabular}{|c|c|c|c|}
\hline $\begin{array}{l}\text { Coded drawing } \\
\text { feature }\end{array}$ & $\begin{array}{l}\text { What this indicates about children's } \\
\text { knowledge }\end{array}$ & Example drawing & $\begin{array}{c}\text { Example comment from interview: "So } \\
\text { what can you tell me about your } \\
\text { drawing?" }\end{array}$ \\
\hline $\begin{array}{l}\text { Sun, bee, other } \\
\text { plant (cactus), } \\
\text { potting soil, } \\
\text { worm, water }\end{array}$ & $\begin{array}{l}\text { Recognized the need for sunlight to } \\
\text { grow } \\
\text { Bees are important to plants } \\
\text { Worms are found in the soil } \\
\text { Potting soil is needed for plants to grow } \\
\text { Water is important (watering can) }\end{array}$ & & $\begin{array}{l}\text { Student: Well ... I think a plant needs } \\
\text { sun to grow ... and there are always } \\
\text { bees around flowers... So they are } \\
\text { important. } \\
\text { Interviewer: Why are they important? } \\
\text { Student: I think they help make } \\
\text { plants-they go from one to another } \\
\ldots \text {. They also need water, so I water my } \\
\text { plants-see my watering can } \\
\text { here-and plants need to have soil ... } \\
\text { we go to Lowes and buy it there for } \\
\text { our plants at my house. }\end{array}$ \\
\hline
\end{tabular}

Table 4. Plant drawings across the grade levels

\begin{tabular}{|c|c|c|}
\hline Structure & Kindergarten & Grade 1 \\
\hline Sunlight & $70 \%$ & $73 \%$ \\
\hline Air & $1 \%$ & $10 \%$ \\
\hline Soil & $29 \%$ & $41 \%$ \\
\hline Ground & $20 \%$ & $35 \%$ \\
\hline Stem & $80 \%(6)^{a}$ & $83 \%(22)$ \\
\hline Roots & $0 \%$ & $14 \%$ \\
\hline Leaves & $6 \%$ & $17 \%$ \\
\hline Petals & $64 \%(3)$ & $84 \%(10)$ \\
\hline Water & $30 \%$ & $59 \%$ \\
\hline Food/fertilizer & $1 \%$ & $6 \%$ \\
\hline Flowers & $64 \%$ & $84 \%$ \\
\hline Trees & $13 \%$ & $28 \%$ \\
\hline Other plants (e.g., cacti, grass) & $11 \%$ & $32 \%$ \\
\hline Seeds & $6 \%$ & $7 \%$ \\
\hline Butterflies & $4 \%$ & $0 \%$ \\
\hline Worms & $0 \%$ & $13 \%$ \\
\hline Bees & $3 \%$ & $14 \%$ \\
\hline Indecipherable drawings & $10 \%$ & $0 \%$ \\
\hline Anthropomorphized (faces) & $10 \%$ & $1 \%$ \\
\hline
\end{tabular}

a Parentheses indicate the percent that were labeled. plants? [student sorts a series of pictures into two piles] ... Can you tell me about what you did?

Mariella: Well ... that looks like grass and grass is a plant, right? [looking at the algae] I'm not sure what that is so I don't think that is a plant ... and this is a mushroom ... I go and pick mushrooms with my mom and dad and we eat them ... So that is definitely a plant.

Interviewer: So why do you think that the mushroom is a plant?

Table 5. Science curricular units for grades $\mathrm{K}-1$ at Kennedy Elementary

\begin{tabular}{lll}
\hline & \multicolumn{2}{c}{ Grade level } \\
\cline { 2 - 3 } Unit & \multicolumn{1}{c}{$\mathrm{K}$} & \multicolumn{1}{c}{1} \\
\hline 1 & Animals & Needs of living organisms \\
2 & Weather & Solid earth materials \\
3 & Properties of objects & Balance and motion \\
4 & Measurement & Properties of solids and liquids \\
\hline
\end{tabular}


Table 6. Is it a plant? Results by grade level

\begin{tabular}{lcc}
\hline \multicolumn{1}{c}{ Structure } & Kindergarten & Grade 1 \\
\hline Grass & $75 \%$ & $79 \%$ \\
Bush & $77 \%$ & $74 \%$ \\
Deciduous tree & $82 \%$ & $73 \%$ \\
Flowers & $73 \%$ & $77 \%$ \\
Coniferous tree & $68 \%$ & $69 \%$ \\
Cactus & $70 \%$ & $67 \%$ \\
Telephone pole & $11 \%$ & $15 \%$ \\
Mushrooms & $59 \%$ & $66 \%$ \\
Algae & $32 \%$ & $16 \%$ \\
Bread mold & $71 \%$ & $76 \%$ \\
Venus flytrap & $47 \%$ & $36 \%$ \\
Seeds & $82 \%$ & $73 \%$ \\
Paper & $20 \%$ & $13 \%$ \\
Peanut butter & $35 \%$ & $14 \%$ \\
\hline
\end{tabular}

Mariella: We go and pick them like we pick flowers ... and then we eat them so they must be a plant 'cause we eat them and I know that it isn't an animal.

Mariella appears to believe that the food we eat can be classified into only two groups, plants and animals. In this particular instance, she understood the mushroom was not an animal. Because she eats mushrooms, this made the mushroom a plant. Similar types of responses occurred with the picture of the bread mold. When students were asked about a picture of bread mold, the most common response was that the mold was a bush and therefore a plant. When asked to explain further, the bread was often described as being the ground where the "bush" grew.

In the interview process, one of the ideas that arose was that students often see different types of plants as their own categories. For example, when asked to sort pictures into two categories (plants/ nonplants) one student, Enrique, placed the flowers in the nonplant pile. When asked to explain his choice, Enrique responded by stating that "flowers were flowers, they are their own special category that doesn't go with plants." Enrique clearly did not acknowledge that flowers were plants. Additionally students did not seem to be able to see how plants are used in other contexts. In this study, $89 \%$ of the kindergarten students and $85 \%$ of the first grade students did not recognize that telephone poles are made from the trunks of trees. When asked about their choices, several students responded that it was a telephone pole, not a plant. When probed further about where these poles might have come from, the most common response was "from the telephone company." This lack of understanding of what everyday household products are made from was further exemplified when asked about paper. Eighty percent of the kindergartners and $87 \%$ of the first graders did not connect paper to trees. Nor did they connect peanut butter to seeds of peanut plants, with $65 \%$ of the kindergartners and $86 \%$ of the first grade students unable to connect peanut butter to peanut seeds. Overall, students could not make the connection between plants and the everyday products that are created from them. This could potentially be due to a lack of connection of plants to everyday experiences and materials within the curriculum.

What Do Plants Need to Survive? In the second portion of the survey, students were asked to identify materials that
Table 7. What do plants need to survive? Survey results

\begin{tabular}{lcr}
\hline \multicolumn{1}{c}{ Needs } & Kindergarten & Grade 1 \\
\hline Bees & $48 \%$ & $63 \%$ \\
Sun & $38 \%$ & $92 \%$ \\
Lightbulb & $14 \%$ & $7 \%$ \\
Cereal & $21 \%$ & $2 \%$ \\
Water & $78 \%$ & $93 \%$ \\
Carbon dioxide & $21 \%$ & $4 \%$ \\
Worms & $54 \%$ & $67 \%$ \\
Air & $49 \%$ & $72 \%$ \\
Oxygen & $56 \%$ & $17 \%$ \\
Sandwich & $14 \%$ & $3 \%$ \\
Plant food & $73 \%$ & $83 \%$ \\
Potting soil & $78 \%$ & $86 \%$ \\
\hline
\end{tabular}

would help a plant to survive and grow (see Table 7). What emerged in this portion of the survey was that there were a number of students in kindergarten (14\%) who stated lightbulbs were a "need" for plants. Additionally, these students tended to believe that cereal $(21 \%)$ and sandwiches $(14 \%)$ were also important for plant survival. These numbers decreased at the first grade level to $7 \%$ for lightbulbs, $2 \%$ for cereal, and $3 \%$ for sandwiches.

During the interviews, when asked to explain about the need for sunlight, Isabella, a first grade student, talked about how chlorophyll was important to help the plants make their food from the sunlight. She had a clear understanding that the light was somehow converted into food for the plant to use. She also talked about how sometimes you could use bulbs in this process. When interviewing Isabella, it became evident that there had been prior work done with plants in her classroom. When probed further, Isabella talked about how they had learned about trees and leaves and how they create food. She talked about how her older sister had grown plants in her class and they had lightbulbs to help them grow. While these experiences help students to gain further understanding of plant's growth, they may have resulted in students taking away that this was needed in addition to or in place of sunlight, creating a new misconception for the students.

Prior research (e.g., Stoddart et al.,1993; Atwood and Atwood, 1997; Abell et al., 1998; Trundle et al., 2002; Davis et al., 2006) demonstrated that elementary teachers often have limited science content knowledge and are highly dependent on curriculum materials to guide their teaching (e.g., Grossman and Thompson, 2004; Mulholland and Wallace, 2005). Curriculum materials can influence teachers' pedagogical decisions and serve as a source of their own science learning (Davis and Krajcik, 2004; Grossman and Thompson, 2004; Remillard, 2005). As a result of their influence on teacher knowledge and plans, enacted curricula can often result in teachers' own misconceptions being conveyed to their students (Grossman and Thompson, 2004).

While the drawings did not necessarily demonstrate that students understood the need for air for the plants to grow and survive (only 1\% of kindergartners and 13\% of first graders drew air), this conceptual knowledge emerged in the surveys portion of the assessment. On average, $61 \%$ of the students across the grade levels grasped the need of the plant to be exposed to air. However, a majority of students were not able to understand the components that make up this 
air, for example carbon dioxide (13\%) and/or oxygen (37\%). Given that this concept is not found in the science standards of early elementary grades (Achieve, 2013), this finding was not surprising.

Another interesting finding emerged in this survey across both grade levels. A subset of students in both grade levels demonstrated an interpretation of plant needs that reflected a plant that had human characteristics. As previously discussed, at the kindergarten level, $14 \%$ of the students thought that plants needed sandwiches and $22 \%$ percent thought that cereal was an important need. These numbers dropped to $3 \%$ and $2 \%$ respectively at the first grade level. This finding connects to the previous studies by Roth (1984) and Smith and Anderson (1984), which demonstrated that young children would often think about food in terms of what a plant might ingest based on their own life experiences. These results also connect to previous studies, which demonstrated that young children anthropomorphize explanations of plant functions (Osborne and Freyberg, 1985; McNair and Stein, 2001; Barman et al., 2006; Anderson et al., 2013). Developmentally, this connects back to Piaget (1951), who believed that anthropomorphism in young children is a result of their egocentricity. He argued that it is "not to be wondered that the child takes personifications of language literally" and that "adult language provides the very conditions necessary to foster children's animism and anthropomorphism and this the more so since, generally speaking, the child takes all metaphors literally" (Piaget, 1951, p. 248). The use of anthropomorphic language and ideas can foster subjectivity in young children; in order to "arrive at an object view of things the mind must free itself from subjectivity and abandon its innate egocentricity... Only qualitative development of the child's mind can lead it to abandon animism" (p. 248). Concurrently, Gallant (1981) found that anthropomorphism can potentially create misconceptions in children, who may not be able to distinguish fact from fiction. He noted that children need to see the world from a nonhuman point of view and unless they are made aware of and understand the problems associated with anthropomorphism, they will not be able to understand why inanimate objects and nonhumans behave the way they do. Still others (e.g., Sharefkin and Ruchlis, 1974) suggest that these types of statements are appropriate for young children who are still in the preoperational and concrete levels of understanding. Anthropomorphic formulations help children in the way they view and make sense of the world.

\section{CONCLUSIONS AND IMPLICATIONS}

As demonstrated by the research (e.g., Tallandini and Valentini, 1991; Stegelin, 2003; Cherney et al., 2006; Brooks, 2009; Einarsdottir et al., 2009), the use of graphic images and drawings has been shown to provide insight into the representation of ideas by children. Drawing and revisiting their ideas allow children to clarify conceptual understandings, resulting in metacognitive growth in developing ideas around complex scientific concepts. The drawings become not only a learning tool but a formative embedded assessment that allows teachers to build up or alter their curricular approaches based on student understanding (Katz, 1993; Katz and Chard, 1996; Wortham, 2001; Palsha, 2002). These drawings can give insight into the development of the children's ideas over a pe- riod of time through revisiting, revising, and talking through the complexities. The children's drawings become a tool for their communication as well as a way for them to demonstrate their problem solving around complex, abstract ideas (Cox, 2005), allowing them to begin to move toward conceptuallevel thinking.

The drawings and surveys in this study provided a great deal of insight into children's conceptual knowledge of plant structure and function. It became clear that some of the children, across the grade levels, had basic knowledge about plant structure and, in some cases, plant function. The drawings and surveys also identified specific misconceptions (e.g., cereal and sandwiches providing food sources for plants) the children had and shed light onto the particular types of experiences and information the children brought to the classroom. Additionally, it became apparent what topics might have been intentionally introduced in an individual classroom. This was particularly true in one of the first grade classrooms, in which some students included specific plant terminology in their drawings and had a much deeper understanding of how plants made food, as reflected in their interviews. For example, some students were able to identify chlorophyll as a component needed for the production of food. Because these are not terms or concepts found in other parts of the first grade curriculum, nor are they a part of the state standards or NGSS at this grade level, it can be assumed the students were representing information that was presented as a part of their classroom curriculum. This was not necessarily true across all of the classrooms and provides insight into the potential conceptual understanding or comfort level of the various classroom teachers with the science content and curriculum (Stoddart et al., 1993; Atwood and Atwood, 1997; Abell et al., 1998; Trundle et al., 2002; Schwartz et al., 2004; Davis et al., 2006). It is also possible that some of the information students brought to their drawings, surveys, and interviews were a result of experiences they had at home with their parents, siblings, or guardians. This should be examined further in future work.

This study also supported the results of previous work with older children and preservice teachers (e.g., Bell, 1981; McNair and Stein, 2001; Tunnicliffe, 2001; Boulter et al., 2003; Gatt et al., 2007). For example, in this study, as well as in previous studies, flowers/flowering plants were drawn more frequently than other types of plants (McNair and Stein, 2001). Children did not typically represent important concepts, such as photosynthesis, in their drawings. This was to be expected, given the age of the children who participated. Most frequently, across both grade levels, simple needs were identified, such as sunlight, water, soil, and nutrients. However, even soil was often omitted. Soil was only shown in $38 \%$ of kindergarten and $45 \%$ of first grade drawings. Those without soil drawn often started their plant drawing at the bottom of the paper, or in the middle of the page, rather than showing the plant emerging from the soil/ground. The inclusion or lack of inclusion may be a direct result of how these concepts are taught or introduced in the science classroom. Additionally, while children demonstrated a lack of advanced conceptual knowledge of plant structure and function in their drawings, the interviews showed that, in some cases, this knowledge was present. The interviews allowed the children to talk about their drawings and representations in a way that encouraged them to work at a metacognitive 
level, problem solving around abstract scientific concepts and giving insight into their conceptual knowledge about plants at a higher level than what was shown in their drawings (Cox, 2005; Brooks, 2009). In this instance, the drawings served as an iconic representation of the children's ideas and sense making about plants with some students demonstrating movement toward more symbolic imagery with their representation of abstract concepts such as use of air or carbon dioxide (e.g., Saunders, 1994; Gabel, 1999; Stanczak, 2007; Einarsdottir et al., 2009; Brooks, 2009).

Several things emerged from analysis of the data from this study. First, the interviews in both of these grades were important to ensure that our interpretation of the drawings was correct. What we found was that drawings not only give insight into student conceptual knowledge, but they also shed light on the types of experiences to which the students have been previously exposed. For example, the high number of cacti drawings could be reflective of the large number of students in the school who were recent immigrants from Latino countries, where these are common types of plants. The use of drawings is particularly useful with younger students who are just learning how to write or learn the language and may not be able to fully express their ideas in written language. However, it was demonstrated through the interviews that it is equally important that teachers provide the opportunities for their students to engage in conversations about their ideas that emerge from their images. These conversations will help students to begin to move along the spectrum from the concrete, iconic images toward more abstract, symbolic representations (Saunders, 1994; Gabel, 1999). Across both grades, it was also apparent that there is a need for greater exposure to plant science through inquiry activities.

The drawings created by the children also function as a formative assessment to help teachers develop inquiry activities that will allow the children to advance their conceptual knowledge. For example, students had some understanding that light was necessary for plant growth. What was not clear was their understanding of how light is used to create food for the plants. By having this knowledge about their students, teachers can develop inquiry activities that would best serve their own students' learning needs in coming to understand how plants function, connecting back to the twelve principles of plants (American Society of Plant Biology, 2014), the state science standards, and the Next Generation Science Standards (Achieve, 2013). An issue that this presents is elementary teachers' comfort with science content knowledge and the teaching of science. Previous research has demonstrated (e.g., Abell and Roth, 1992; Tosun, 2000; Appleton, 2006; Davis et al., 2006) that elementary teachers have limited science content knowledge (Abell and Roth, 1992; Davis et al., 2006) and a low confidence to teach science (Tosun, 2000). For the assessment we have done here to be an effective formative assessment, additional training of teachers would be needed. Future work may include the development of teacher professional development in the use of drawing as a formative assessment.

Within a science classroom, drawings can play an important role by creating the opportunity for open-ended, creative assessment that provides teachers with insight into their students' conceptual knowledge. While written assessments are still the most common forms of assessment in science classrooms, drawings provide the types of insight that can be used to inform both teaching and learning processes. Drawing becomes a "constructive process of thinking in action" (Cox, 2005, p. 123). While the assessments did not necessarily reflect student growth in this study, this may be due to the fact that the study was not embedded within the curricular units dealing with plants. Other limitations of this study are that it represents findings of one context, Kennedy Elementary School, and teachers' conceptual understanding of plants and their integration of science into classroom practices was not considered. Future studies should incorporate these assessments and curricular materials into the typical units that include plant science in order to create a context for student learning. However, what the drawings did demonstrate was that students' conceptual understanding was on a spectrum that ranged from the concrete, iconic images to the abstract, symbolic representations of plants and their functions. In further studies, the impact of teachers' conceptual knowledge and the role it plays in the enactment of plant science curriculum in the classroom and the role of culture on children's understanding of plants should be examined.

\section{REFERENCES}

Abell SK, Bryan LA, Anderson MA (1998). Investigating preservice elementary science teacher reflective thinking using integrated media case-based instruction in elementary science teacher preparation. Sci Educ 82, 491-509.

Abell SK, Roth M (1992). Constraints to teaching elementary science: a case study of a science enthusiast student teacher. Sci Educ 76, 581-595.

Achieve (2013). Next Generation Science Standards: For States, By States, Washington, DC: National Academies Press.

American Society of Plant Biology (2014). Principles of Plant Biology: Concepts for Science Education. http://my.aspb.org/?page =EF_Principles (accessed 25 November 2013).

Anderson J, Ellis J, Jones AJ (2013). Students conceptual understanding of plant structure and function. Paper presented at the Annual International Meeting of the National Association for Research in Science Teaching, held April 6-9, 2013, in Rio Grande, PR

Appleton K (2006). Science pedagogical content knowledge and elementary school teachers. In: Elementary Science Teacher Education, ed. K Appleton, Mahwah, NJ: Lawrence Erlbaum, 31-54.

Athney C (1990). Extending Thought in Young Children, London: Paul Chapman.

Atwood RK, Atwood VA (1997). Effects of instruction on pre-service elementary teachers' conceptions of the causes of night and day and the seasons. J Sci Teach Educ 8, 1-13.

Barab SA, Barnett M, Yamagata-Lynch L, Squire K, Keating T (2002). Using activity theory to understand the systemic tensions characterizing a technology-rich introductory astronomy course. Mind Cult Act 9, 76-107.

Barman CR, Stein M, Barman N, McNair S (2002). Assessing student ideas about plants. Sci Child 10, 25-29.

Barman CR, Stein M, McNair S, Barman S (2006). Students' ideas about plants and plant growth. Am Biol Teach 68, 73-79.

Bell BF (1981). What is a plant? Some children's ideas. New Zealand Sci Teach 31, 10-14.

Bodrova E (2008). Make-believe play versus academic skills: a Vygotskian approach to today's dilemma of early childhood education. Eur Early Child Educ Res J 16, 357-369.

Boulter C, Tunnicliffe SD, Reiss M (2003). Probing children's understandings of the natural world. In: Biology Education for the Real 
World: Proceedings of the 4th Conference of European Researchers in Didactic of Biology (ERIDOB), Toulouse, France: Ecole Nationale de Formation Agronomique, 243-257.

Brecht M, Schmitz D (2008). Neuroscience: rules of plasticity. Science $319,39$.

Bredekamp S (2006). Staying true to our principles. J Educ Young Child 12, 21-24.

Brooks M (2009). Drawing, visualization and young children's exploration of "big ideas." Int J Sci Educ 31, 319-341.

Carey S (2004). Bootstrapping and the origins of concepts. Daedalus $133,59-68$.

Chambers DW (1983). Stereotypical images of the scientist: the DrawA-Scientist test. Sci Educ 67, 255-266.

Charmaz K (2006). Constructing Grounded Theory: A Practical Guide through Qualitative Analysis, Chicago: Pine Forge.

Cherney ID, Seiwert CS, Dickey TM, Flichbeil JD (2006). Children's drawings: a mirror to their minds. Educ Psychol 26, 127-142.

Cox S (2005). Intention and meaning in young children's drawing. Int J Art Des Educ 24, 115-125.

Davis EA, Krajcik J (2004). Supporting inquiry-oriented science teaching: design heuristics for educative curriculum materials. Paper presented at the Annual meeting of the American Educational Research Association, held April 2004, in San Diego, CA.

Davis EA, Petish D, Smithey J (2006). Challenges new science teachers face. Rev Educ Res 76, 607-651.

Einarsdottir J, Dockett S, Perry B (2009). Making meaning: children's perspectives expressed through drawings. Early Child Dev Care 179, 217-232.

Finson KD (2003). Applicability of the DAST-C to the images of scientists drawn by students of different racial groups. J Elementary Sci Educ 15, 15-26.

French L (2004). Science as the center of a coherent, integrated early childhood curriculum. Early Child Res Q 19, 138-149.

Gabel D (1999). Improving teaching and learning through chemistry education research: a look to the future. J Chem Educ 76, 548.

Gallant RA (1981). Pitfalls of personification. Sci Child 19, 16-17.

Gatt S, Tunnicliffe SD, Borg K, Lautier K (2007). Young Maltese children's ideas about plants. J Biol Educ 41, 117-122.

Gauld C (1989). A study of pupils' responses to empirical evidence. In: Doing Science: Images of Science in Science Education, ed. R Millar, London: Falmer, 62-82.

Golomb C (1992). The Child's Creation of a Pictorial World, Berkeley: University of California Press.

Goodenough F (1926). Measurement of Intelligence by Drawings, New York: Harcourt.

Grossman P, Thompson (2004). District policy and beginning teachers: a lens on teacher learning. Educ Eval Policy Anal 26, 281-301.

Grungeon E (1993). Gender implications of children's playground culture. In: Gender and Ethnicity in Schools: Ethnographic Accounts, ed. P Woods and M Hamersley, London: Routledge, 11-33.

Haney W, Russell M, Bebell D (2004). Drawing on education: using drawings to document schooling and support change. Harv Educ Rev 74, 241-271.

Howe C, Tolmie A, Rodgers C (2011). The acquisition of conceptual knowledge in science by primary school children: group interaction and the understanding of motion down an incline. Br J Dev Psychol 10, 113-130.

Katz LG (1993). What can we learn from Reggio Emilia? In: The Hundred Languages of Children: The Reggio Emilia Approach to Early Childhood Education, ed. C Edwards, L Gandini, and G Forman, Columbus, $\mathrm{OH}$ : Merrill.
Katz LG, Chard SC (1996). The Contribution of Documentation to the Quality Of Early Childhood Education, ERIC Digest No. EDO-PS-96-2. http://ecap.crc.illinois.edu/eecearchive/digests/ 1996/lkchar96.html.

Kellogg R (1969). Analyzing Children's Drawings, Palo Alto, CA: Mayfield.

Kress G (1997). Before Writing: Re-thinking the Paths to Literacy, London: Routledge.

Kuhn D, Pearsall S (2000). Developmental origins of scientific thinking. J Cogn Dev 1, 113-129.

Lally D, Brooks E, Tax FE, Dolan EL (2007). Dialogue: public engagement through plant science. Plant Cell 19, 2311-2319.

Larkin D (2012). Misconceptions about "misconceptions": pre-service secondary science teachers' views on the value and role of student ideas. Sci Educ 96, 927-959.

Light P (1985). The development of view specific representation considered from a socio-cognitive standpoint. In: Visual Order: The Nature and Development of Pictorial Representation, ed. NH Freeman and MV Cox, Cambridge, UK: Cambridge University Press, 214230 .

Lincoln YS, Guba EG (1985). Naturalistic Inquiry, Newbury Park, CA: Sage.

McNair S, Stein M (2001). Drawing on their understanding: using illustrations to invoke deeper thinking about plants. Paper presented at the Association for the Education of Teachers of Science Annual Meeting, held January 18-21, 2001, in Costa Mesa, CA.

Mulholland J, Wallace J (2005). Growing the tree of teacher knowledge: ten years of learning to teach elementary science. J Res Sci Teach 42, 767-790.

National Research Council (NRC) (1996). National Science Education Standards, Washington, DC: National Academies Press.

NRC (2012). A Framework for Science Education, Washington, DC: National Academies Press.

Opfer JE, Siegler RS (2004). Revisiting preschoolers living things concept: a microgenetic analysis of conceptual change in basic biology. Cogn Psychol 49, 301-332.

Osborne RJ, Freyberg P (1985). Learning in Science, London: Heinemann.

Palsha S (2002). An outstanding education for all children: learning from Reggio Emilia's approach to inclusion. In: Teaching and Learning Collaborative Exploration of the Reggio Emilia Approach, ed. V Fu, A Stremmel, and L Hill, Columbus, OH: Merrill, 109129.

Piaget J (1951). The Child's Conception of the World, Savage, MD: Littlefield Adams.

Piaget J, Inhelder B (2013). The Growth of Logical Thinking from Childhood Adolescence: An Essay on the Construction of Formal Operational Structures, New York: Routledge.

Remillard JT (2005). Examining key concepts in research on teachers' use of mathematics curricula. Rev Educ Res 75, 211-246.

Ring K (2006). Supporting young children drawing: developing a role. Int J Educ Art 2, 195-209.

Ross PA, Tronson D, Ritchie RAJ (2006). Modeling photosynthesis to increase conceptual understanding. J Biol Educ 40, 84-88.

Roth KJ (1984). Using classroom observations to improve science teaching and curriculum materials. In: Observing Science Classrooms: Perspectives from Research and Practice, 1984 Yearbook of the Association for the Education of Teachers in Science, ed. CW Anderson, Columbus, OH: ERIC/SMEAC.

Sanders D (2007). Making public the private life of plants: the contribution of informal learning environments. Int J Sci Educ 29, 1209 1228. 
Saunders AC (1994). Graphics and how they communicate. In: Visual Literacy: A Spectrum of Visual Learning, ed. DM Moore and FM Dwyer, Englewood Cliffs, NJ: Educational Technology.

Schneekloth L (1989). "Where did you go?" “The forest." "What did you see?" "Nothing." Children's Environments Q 6, 14-17.

Schwartz RS, Lederman NG, Crawford BA (2004). Science teacher education: developing views of nature of science in an authentic context: an explicit approach to bridging the gap between nature of science and scientific inquiry. Sci Educ 88, 610-645.

Sharefkin B, Ruchlis H (1974). Anthropomorphism in the lower grades. Sci Child 11, 37-40.

Smith EL, Anderson CW (1984). Plants as producers: a case study of elementary science teaching. J Res Sci Teach 21, 685-698.

Smith JP, diSessa AA, Roschelle J (1993). Misconceptions reconceived: a constructivist analysis of knowledge in transition. J Learn Sci 3, 115-163.

Stanczak GC (2007). Introduction: images, methodologies and generating social knowledge. In: Visual Research Methods: Image, Society and Representation, ed. GC Stanczak, Thousand Oaks, CA: Sage, $1-21$.

Stegelin DA (2003). Application of the Reggio Emilia approach to early childhood science curriculum. Early Child Educ J 30, 163-170.

Stoddart T, Connell M, Stofflett R, Peck D (1993). Reconstructing elementary teacher candidates' understanding of mathematics and science content. Teach Teach Educ 9, 229-241.
Suping S (2003). Conceptual Change among Students in Science. ERIC Clearinghouse for Science Mathematics and Environmental Education. http:/ / files.eric.ed.gov/fulltext/ED482723.pdf.

Tallandini MA, Valentini P (1991). Symbolic prototypes in children's drawings of schools. J Genet Psychol 152, 179-190.

Tosun T (2000). The beliefs of preservice elementary teachers toward science and science teaching. Sch Sci Math 100, 374-379.

Trundle KC, Atwood RK, Christopher JE (2002). Pre-service elementary teachers' conceptions of moon phases before and after instruction. J Res Sci Teach 39, 633-658.

Tunnicliffe SD (2001). Talking about plants: comments of primary school groups looking at plant exhibits in a botanical garden. J Biol Educ 36, 27-35.

Vosniadou S (2002). On the nature of naive physics. In: Reconsidering Conceptual Change: Issues in Theory and Practice, ed. M Limon and L Mason, Dordrecht, The Netherlands: Kluwer, 61-76.

Wandersee JH, Schussler EE (2001). Toward a theory of plant blindness. Plant Sci Bull 47, 2-9.

Weber S, Mitchell C (1995). “That's Funny, You Don't Look Like a Teacher," Washington, DC: Falmer.

Wee B (2012). A cross-cultural exploration of children's everyday ideas: implications for science teaching and learning. Int J Sci Educ 34, 609-627.

Wortham SC (2001). Assessment in Early Childhood Education, Upper Saddle River, NJ: Prentice Hall. 